\title{
Promotion of investment in renewable energy projects
}

\author{
Anna Rumyantseva ${ }^{1 *}$, Svetlana Zhutyaeva ${ }^{1}$, and Natalya Lazareva ${ }^{1}$ \\ ${ }^{1}$ St. Petersburg University of Management Technologies and Economics, 44, Lermontovsky Prospekt, \\ 190103, St. Petersburg, Russia
}

\begin{abstract}
The article presents the need for the development of renewable energy sources due to the improvement of energy efficiency, safety, and environmental conditions; there is also a worldwide state interest in this area of development. An overview of the production of electricity from renewable energy sources in the world since 1990 is made, and it is noted that the fastest development rates are observed in the solar and wind energy development. The global market for environmental projects financing is analyzed, the instruments for renewable energy projects financing are evaluated, and the green bond market state is presented in detail. Directions for further policies aimed at encouraging increased investment in renewable energy sources are proposed.
\end{abstract}

\section{Introduction}

Natural renewable energy sources (RES) that include biomass, wind, water resources, and solar radiation were the main sources of energy in the early stages of civilization. Herewith technologies at that time were simple and primitive and allowed receiving energy in small quantities. In the $20^{\text {th }}$ century, the use of oil and gas production technologies began to lead to a decrease in the share of biomass and coal in the global energy structure.

The "Energy Crisis" began in 1970s, and it became obvious that oil cannot be a reliable and long-term basis for the global energy industry; diversification of energy sources is required. The active development of nuclear energy began, but it slowed down due to the Chernobyl disaster; along with this, the world's concern about the level of human influence on the ecological situation began to increase [1-4].

Renewable energy sources in Russia are developing in three types or directions: solar energy, small hydropower, and wind power. In Russia, compared to other countries, these sources of energy development is extremely slow. The wind energy implementation in Russia is realized by the Vitroen research and production association that develops projects and produces small batches of wind turbines with a capacity of $2-5 \mathrm{~kW}$. This product is used in areas that are remote from centralized places of energy supply.

Russian research and production facilities have mastered the production of power plants with solar panels, wind power stations, small hydro stations; in addition, biogas plants for individual and private farms. "A technology to produce bioethanol from a dangerous weed

\footnotetext{
*Corresponding author: post_graduate@mail.ru
} 
- Hogweed - that produces four times more fuel than from sugar cane has been patented; and scientists from the Siberian Institute of Plant Physiology and Biochemistry of the SB RAS have recently proposed to produce biofuels from poplars. They have already created transgenic fast-growing pyramidal poplars for it that can be bred on special plantations" [5].

\section{Methodology and theory}

Many countries have begun active research to find alternative environmentally safe energy sources that include natural renewable energy sources. It should be noted that at the end of 2017 the leading countries in terms of total installed capacity of renewable energy sources were: Norway, Canada, Brazil, Colombia, Russia accounts for $17 \%$.

The fastest rates of development are observed in the solar and wind energy development. In 2015, the one-year market was 10 times more than the total global market ten years ago. China, Japan and the United States re-introduced most of the new capacities. In the same year, wind energy was the main source of new capacities in the United States and Europe, and the second largest in China. In Sweden, about $80 \%$ of road transport consumes bioethanol; since 2006 Brazil has been actively using bioethanol from sugar cane [7].

Table 1. Renewable energy sources share in electricity production (including hydro ones), $\%$.

\begin{tabular}{|c|c|c|c|c|c|c|c|c|c|}
\hline & 1990 & 2000 & 2010 & 2012 & 2013 & 2014 & 2015 & 2016 & 2017 \\
\hline World & 19.74 & 18.79 & 19.93 & 21.22 & 22.01 & 22.71 & 23.13 & 24.08 & 24.80 \\
\hline European Union & 12.63 & 14.78 & 21.11 & 24.23 & 27.20 & 29.19 & 29.86 & 30.19 & 30.18 \\
\hline Germany & 3.90 & 6.89 & 17.57 & 23.75 & 24.76 & 26.82 & 29.88 & 30.02 & 33.98 \\
\hline Norway & 99.79 & 99.72 & 95.75 & 97.97 & 97.71 & 97.67 & 97.73 & 97.87 & 97.87 \\
\hline Russia & 15.34 & 18.85 & 16.28 & 15.68 & 17.29 & 16.72 & 16.01 & 17.45 & 17.51 \\
\hline America & 25.21 & 23.59 & 25.57 & 27.56 & 27.83 & 28.02 & 27.98 & 29.81 & 32.08 \\
\hline North America & 18.53 & 15.55 & 16.77 & 18.98 & 19.76 & 19.96 & 20.27 & 22.01 & 24.40 \\
\hline Canada & 62.39 & 60.61 & 61.40 & 63.24 & 63.30 & 62.83 & 63.02 & 64.08 & 64.71 \\
\hline United States & 11.96 & 8.81 & 10.61 & 12.41 & 13.03 & 13.36 & 13.63 & 15.42 & 17.66 \\
\hline Latin America & 66.06 & 61.70 & 57.48 & 55.81 & 54.07 & 53.96 & 52.52 & 54.41 & 56.04 \\
\hline Colombia & 76.38 & 75.52 & 72.12 & 79.55 & 74.00 & 74.04 & 68.24 & 72.11 & 86.78 \\
\hline Asia & 17.49 & 13.24 & 15.76 & 17.00 & 17.69 & 19.10 & 19.92 & 20.79 & 21.43 \\
\hline China & 20.41 & 16.64 & 18.83 & 20.12 & 20.45 & 22.79 & 24.13 & 25.40 & 25.97 \\
\hline Pacific & 22.56 & 18.77 & 18.70 & 20.13 & 22.58 & 24.69 & 23.77 & 25.96 & 24.92 \\
\hline Australia & 10.08 & 8.54 & 8.63 & 10.61 & 13.30 & 14.92 & 13.67 & 15.78 & 14.95 \\
\hline New Zealand & 80.01 & 71.50 & 73.18 & 71.87 & 74.26 & 79.20 & 80.08 & 84.17 & 81.39 \\
\hline Africa & 18.40 & 17.78 & 17.51 & 16.66 & 17.12 & 17.95 & 17.79 & 17.50 & 18.11 \\
\hline Nigeria & 32.59 & 38.22 & 24.40 & 19.71 & 18.44 & 17.59 & 18.20 & 18.20 & 18.21 \\
\hline Middle-East & 4.88 & 1.71 & 2.03 & 2.28 & 2.50 & 1.99 & 1.75 & 2.17 & 2.14 \\
\hline Iran & 10.29 & 3.04 & 4.16 & 4.99 & 5.71 & 5.20 & 5.10 & 5.72 & 5.14 \\
\hline
\end{tabular}

Source: https://yearbook.enerdata.ru/renewable-in-electricity-production-share-by-region.html

Significant amounts of money are invested by the United Arab Emirates in renewable, alternative energy sources in Europe, Africa, and Asia. They have set a task to bring the 
share of such energy to $7 \%$ of the country energy capacity total consumption by 2020 . The Chinese government has set an ambitious goal - to increase the share of non-fossil fuels in primary energy consumption by about $30 \%$ by 2030 [3]. In 2017, global new investments in renewable energy and fuel sources, excluding hydropower projects, amounted to $\$ 279.8$ bn that is $2 \%$ more than in 2016; but investments in 2016 decreased by $23 \%$ compared to 2015 from $\$ 323$ bn to $\$ 274$ bn (see Figure 1). Investments in large hydropower projects amounted to approximately $\$ 45$ bn in 2017 .

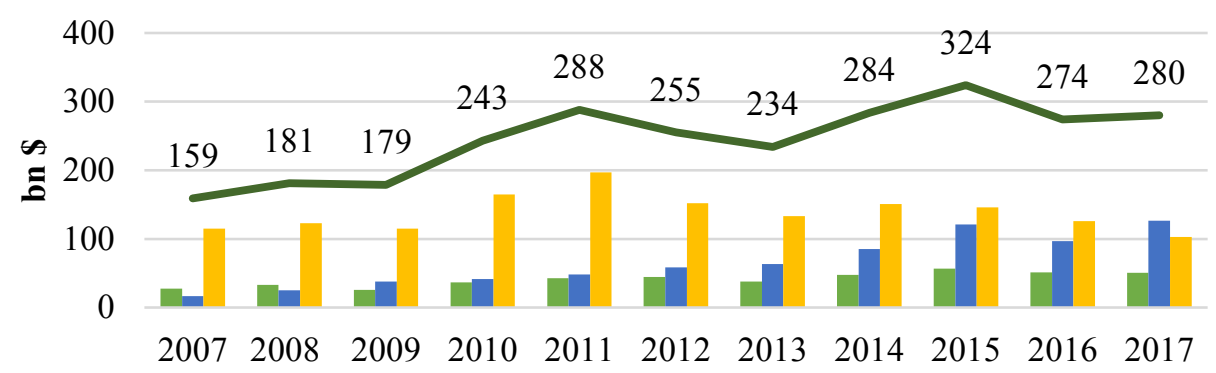

Developing and transition economies

China

Developed countries

Total in the world

Fig. 1. Global new investments in renewable energy and fuels in developed, developing and transition economies, 2007-2017 Source: http://www.ren21.net/status-of-renewables/global-status-report

Now investors can buy more renewable energy capacities for less money as a result of a significant reduction in the cost of solar and wind energy facilities. For the full energy transition implementation it is not enough to focus only on the electricity sector; for example, there is much less investment in the renewable energy sector for heating and cooling. Investments in renewable energy in developed countries, in general, declined by $18.3 \%$ in 2017 , despite significant volumes of capacity commissioning. Investments decreased in developed countries such as the USA (by $6 \%$ or $\$ 2.6$ bn) and Japan (by $28 \%$ or $\$ 5.2 \mathrm{bn}$ ) and in leading European countries: Germany (by $35 \%$ or $\$ 5.6 \mathrm{bn}$ ) and the UK (by $65 \%$ or $\$ 14.1 \mathrm{bn}$ ). However, there is still a need for policies aimed at encouraging increased investments in renewable energy, creation of technologies and the necessary infrastructure in accordance with the new reality of renewable energy; for example, cost reduction, increasing the share of variable renewable energy sources, the need to increase maneuverability and interconnection of sectors, etc.

Compared with the objects of traditional generation, renewable energy projects have a large ratio of initial capital costs to operating costs that makes them very sensitive to the price of capital. According to IRENA estimates, the normalized flattened cost of generating a wind farm rises by about $60 \%$ with the price of capital rising from $5.5 \%$ to $14.5 \%$. The relative impact of the cost of capital will increase as technology costs fall [6].

However, it should be noted that the cost of capital for renewable energy projects is currently falling, as risks can be more accurately assessed and predicted now; and, in addition, investors are increasingly aware of the benefits and opportunities that renewable energy projects offer. Depending on the project expected cash flows and the risks involved, for most renewable energy projects in developed markets the cost of capital is $6-10 \%$; in developing markets this figure is still higher. 
Assets in the renewable energy market have many advantages that attract institutional investors, including regular annual income, long investment horizons, long-term and largescale capital protection strategies - especially when there are "green" tariffs or similar incentive mechanisms. In addition, to date some institutional investors are seeking to implement a model whereby making direct investments implies "nurturing" their own resources so that they can be directly involved in investment portfolios management in the future - the costs are reduced that in turn leads to increase of net profit from investing activities. This model is especially common in Canada, Australia, and Europe, particularly in Germany and the Scandinavian countries. However, institutional investors should be aware of the fact that the mission of independent managers is not limited to the provision of services - in most cases they all have significant experience and technical capabilities that are so necessary for effective customer support at all stages of investment activity; direct investors are deprived of it.

The global market in the renewable energy sector continues to grow rapidly. Since 2010 , this segment has maintained a positive trend, and the number of transactions continues to increase. In 2017, there were 406 transactions in the world, the total value of them amounted to 40.1 bn euros. Table 2 .

Table 2. Largest deals in renewable energy sector in 2017

\begin{tabular}{|c|c|c|c|c|c|}
\hline $\begin{array}{l}\text { Announced } \\
\text { date of } \\
\text { transaction }\end{array}$ & $\begin{array}{l}\text { Transaction object } \\
\text { (purchased } \\
\text { company) }\end{array}$ & $\begin{array}{c}\text { Transaction } \\
\text { object } \\
\text { country }\end{array}$ & Buying company & $\begin{array}{l}\text { Buying } \\
\text { company } \\
\text { country }\end{array}$ & $\begin{array}{l}\text { Transaction } \\
\text { amount, bn } \\
\text { euros }\end{array}$ \\
\hline $\begin{array}{l}7 \text { March } \\
2017\end{array}$ & $\begin{array}{l}\text { TerraForm Power, } \\
\text { Inc. }(38.84 \% \text { of } \\
\text { stocks) }\end{array}$ & USA & $\begin{array}{l}\text { Brookfield Asset } \\
\text { Management Inc. }\end{array}$ & Canada & 4013 \\
\hline $\begin{array}{l}31 \text { October } \\
2017\end{array}$ & $\begin{array}{l}\text { Orsted (Walney } \\
\text { Extension - coast } \\
\text { wind power } \\
\text { station, } 50 \% \text { of } \\
\text { stocks) }\end{array}$ & Great Britain & $\begin{array}{l}\text { PKA A/S; PFA Pension } \\
\text { Forsikringsaktieselskab } \\
\text { AS }\end{array}$ & Denmark & 2274 \\
\hline $\begin{array}{l}\text { 24 February } \\
2017\end{array}$ & $\begin{array}{l}\text { Sustainable Power } \\
\text { Group, LLC }\end{array}$ & USA & $\begin{array}{l}\text { AES Corporation; Alberta } \\
\text { Investment Management } \\
\text { Corporation }\end{array}$ & Canada & 1490 \\
\hline $\begin{array}{l}7 \text { March } \\
2017\end{array}$ & $\begin{array}{l}\text { TerraForm } \\
\text { Global, Inc. }\end{array}$ & USA & $\begin{array}{l}\text { Brookfield Asset } \\
\text { Management Inc. }\end{array}$ & Canada & 1171 \\
\hline $\begin{array}{l}7 \text { August } \\
2017\end{array}$ & $\begin{array}{l}\text { Borkum Riffgrund } \\
2(50 \% \text { of stocks })\end{array}$ & Germany & $\begin{array}{l}\text { Global Infrastructure } \\
\text { Partners }\end{array}$ & USA & 1170 \\
\hline $\begin{array}{l}2 \text { August } \\
2017\end{array}$ & $\begin{array}{l}\text { Energy } \\
\text { Development } \\
\text { Corporation } \\
(47.5 \% \text { of stocks })\end{array}$ & Philippines & $\begin{array}{l}\text { Consortium for Energy } \\
\text { Development Corp }\end{array}$ & Singapore & 1080 \\
\hline $\begin{array}{l}22 \\
\text { December } \\
2017\end{array}$ & $\begin{array}{l}\text { InterGen (actives } \\
\text { in Mexico) }\end{array}$ & Mexico & Actis LLP & $\begin{array}{l}\text { Great } \\
\text { Britain }\end{array}$ & 1060 \\
\hline $\begin{array}{l}7 \text { March } \\
2017\end{array}$ & $\begin{array}{l}\text { OAO RusGydro } \\
(12.46 \% \text { of } \\
\text { stocks })\end{array}$ & Russia & OAO Bank VTB & Russia & 869 \\
\hline
\end{tabular}

Source: $\quad$ https://home.kpmg.com/ru/ru/home/insights/2018/05/great-expectations-deal-making-intherenewable-energy-sector.html

The priority program for RAO ES Vostoka (RusGydro subsidiary) is the Program for the renewable energy development in isolated areas of the Far East. The policy of building energy complexes using a renewable resource will allow RAO ES Vostoka not only to control tariffs for the population in the future but also to provide all regions of the Far East with energy, using the latest equipment for the renewable energy projects implementation. In 2015 PAO RAO ES Vostoka built 11 solar power plants and 4 wind power stations in the Far East. [6]. 
The global market for environmental projects financing is a little over $\$ 400 \mathrm{bn}$. And most of them are green bonds - about 98\%. For five years, from 2013 to 2017, the green bond market has grown more than 13.5 times. As of 1 May, 2018, the green bond market volume amounted to $\$ 377.3 \mathrm{bn}$. In 2017, 47\% of issues accounted for the USA and Mexico (34\% and 13\% respectively). In the first quarter of 2018 bonds worth almost $\$ 25.5$ bn were placed: almost half of the bonds were issued by Sweden (15\%), China (14\%) and the USA $(13 \%)$. Most of the funds are directed to the alternative energy development projects $(33 \%)$, construction of buildings with low energy consumption (29\%) and the ecological transport creation (15\%). In Russia this tool has not entered the market yet, but the Central Bank announced the first pilot issues of green Eurobonds that are planned to be placed in 2018 . Depending on demand, the regulator will think whether it is necessary to produce them in the domestic market. Currently, more than 60\% of issued "green" bonds (marked and unmarked) have a maturity of more than 10 years, about $30 \%$ - from 5 to 10 years, only about $6 \%$ - from 3 to 5 years.

The development and publication of the first standard of climate bonds (in the field of wind energy generation) and their certification scheme by the international non-profit organization Climate Bond Initiative (CBI) at the end of 2011 can be considered as the beginning of green bonds standardization. In 2012-2015, four sectoral CBI standards were developed and approved for projects in the field of solar energy, low-carbon public transport (high-speed bus), and energy-efficient buildings.

Today, different organizations are green debt securities issuers - supranational (European Investment Bank, World Bank), municipal / provincial / national governments (Paris, Massachusetts, Ontario, Government of Poland and France), banks (Bank of America, Credit Agricole), large corporations (Apple, Toyota), target companies (trusts, partnerships) and various government agencies (Export Development Canada, New York Metropolitan Transport Authority).

"Green" bonds also guarantee debt repayment in a timely manner and payment of a fixed or floating interest rate. The only difference is the labeling that indicates the direction of funds from emissions to green projects. Currently labeling is carried out on the basis of international rules and procedures contained in the Green Bond Principles and the Climate Bond Standard adopted by international organizations that are not binding. At the same time, according to many experts, green bonds certification in the coming years may become mandatory in many countries. "Green" financing in Russia is still in its infancy. At the moment, there are no generally accepted and legally enforced definitions of "green" investments, criteria for classifying projects as "green" and an effective system of control over financial institutions compliance with social and environmental standards in practice.

To finance renewable energy projects, new financial instruments are being created that are suitable for a number of investment portfolios - from the small financial community to large investment funds. New aggregated tools help to overcome certain investment barriers, such as, for example, the insufficient scale of the project (the project is too small for an institutional investor), the lack of quality information, the developer unreliability, etc. Such tools as crowdfunding or public funding and sunny leasing should be emphasized.

Crowdfunding is based on the principle completely opposite to green bonds. There are a lot of investors here, ordinary people can be among them; in small shares they finance decentralized, cooperative projects of renewable energy sources. One of the most successful crowdfunding projects is Mosaic, the American market leader. Crowdfunding or public funding was originally designed to finance innovative creative projects without receiving any financial income. However, subsequently innovative companies began to allow a large number of investors to buy small shares of capital in renewable energy projects. This principle formed the basis of crowdfunding in its current sense. Crowdfunding helps to reduce the cost of capital for an investor, including in developing countries. The pioneer of 
public funding, Kiva.org, has already allocated over $\$ 600 \mathrm{mln}$ of loans to small businesses in 78 countries. Such organizations could carry out investment activities on a global scale that would finance specific projects in markets for which access to capital is limited due to some barriers.

The principle of solar leasing is that rooftop solar panels are provided for the possession, use and disposal of third parties, while the owner of the equipment receives an appropriate reward in the form of reducing electricity bills, or through direct payments. This provides cheaper electricity to the equipment owner, without the need for making large investments. Panel owners get their income through political incentives and electricity sales. This funding mechanism was a success in the USA, as well as in Italy and Bangladesh. Constant, reliable and long-term framework conditions for the energy sector functioning and state creditworthiness are key prerequisites for the success of risk reduction measures for investors in renewable energy projects. A good example of this is the 500 MW concentrated solar power plant in Morocco that will become the largest CS power plant in the world. The first $120-160 \mathrm{MW}$ of capacity was commissioned in 2015 . The project is unique in its kind, since several investors merged with the government and international financial institutions that, in turn, focused their efforts on risk reduction [8].

It should also be noted that in Russia a mechanism of state guarantees for bond loans is used, it can also be applied to green bonds. In particular, the Decree of the Government of the Russian Federation of 14 December, 2010 No. 1016 "On Approval of the Rules for the Selection of Investment Projects and Principals for Providing State Guarantees of the Russian Federation for Credits or Bonded Loans Involved to Implement Investment Projects" laid the possibility of providing state guarantees for investment projects related to energy conservation and energy efficiency increase in the field of housing and utilities and industry. In addition, the experience of the FSII Russian Fund for Industry Development that is aimed to provide loans for new high-tech products, technical re-equipment and creation of competitive industries based on the best available technologies can be useful for the development of state lending instruments for "green" projects. Rules according to which the fund can direct money in the framework of PPP to introduce the best available technologies are developed.

Policies aimed at encouraging increased investments in renewable energy sources should be carried out in the following areas:

1. It is advisable to issue "green" project bonds at the stage when the infrastructure project was made and the production of goods and services began that provides a steady stream of income for the payment on bonds. In this case, the issue of "green" bonds is used as a mechanism for refinancing short-term debt on a bank loan taken for construction.

2. Important measures to support the "green" bond market are measures to reduce the cost of bank credit used in transactions with "green" bonds. In a number of countries environmental criteria are increasingly being used to regulate bank reserves and capital requirements that reduce the cost of "green" borrowing and simultaneously reduce access to "dirty" technologies. Thus, the Central Bank of China does not include loans related to operations on "green" bonds in the calculation of one of the banks liquidity indicators (the index that establishes the ratio of the volume of loans and deposits). For banks lending to the purchase of "green" bonds, these loans have preferential weights when calculating capital adequacy.

\section{Discussion}

The neoclassical school of economics deals with two key areas in the environment: the assessment of environmental assets and the development of policy instruments for managing these assets. Its founders include Herman Daly, Peter Robert Hay, Joan Martinez 
Alier, Robert Costanza, and others. The essence of the neoclassical concept is that the market provides for an optimal resources distribution and all resources are interchangeable, that is, when there is a shortage of resources, a change in their prices occurs that stimulates the development of new technologies and the emergence of new resources.

The studies of M. Taylor, A. Khalid, M. Haller and others are devoted to the issues of economic, social and environmental effects of the renewable energy development. The papers of D. Nickolls, P. Gross, A. Castillo, A. Held, M. Ragwitz, P. Mitchell, K. Kunz and others evaluate the policy of supporting renewable energy.

There are almost no fundamental works on the renewable energy development in Russia (with the exception of large hydropower plants). This is partly due to the fact that renewable energy in Russia practically does not exist as a full industry of energy. The Russian sector of renewable energy as an object of research is absent on a tangible scale that makes it difficult to study and analyze.

\section{Conclusion}

The main conclusions are as follows:

- financing mechanisms for "green" investment projects do not have fundamental differences and are implemented in the same environment where traditional investment projects are financed that cannot but cause competition between them;

- due to the novelty of technology and little knowledge of the markets for which "green" products are oriented, "green" investment projects are more costly and less predictable that requires an additional incentive to encourage investors to take on the risks of investments;

- state intervention allows stimulation of the process of moving private capital from "dirty" to "green" investments in volumes adequate to meet the challenges of sustainable growth in an acceptable timeframe. At the same time, the state should play the role of a catalyst, rather than an alternative source of funding for "green" projects;

- for the state, it is important to ensure the "launching" of the market for green bonds first of all, creating favorable conditions for all stakeholders and market participants and balancing their economic interests. But in strategic terms, it is even more important for the state to coordinate the development of this market with the solution of macroeconomic tasks related to the financial system stabilization and "green" growth.

\section{References}

1. First International Forum Renewable Energy: Ways to Improve Energy and Economic Efficiency (REENFOR-2015)

2. L. Razumnova, Oil of Russia 5, 80-84 (2012)

3. Climate Bonds Initiative et al. Bonds and climate change: the state of the market in 2015 , https://www.climatebonds.net/files/files/CBIHSBC\%20report\%207July\%20JG01.pdf

4. URL: http://climatepolicyinitiative.org/publication/effective-greenfinancingwhathave-welearned-so-far/

5. URL : www. wsj.com / articles / investors-warm-to-green-bonds-1491790201 6 . REthinking Energy: Towards a new power system, IRENA,

6. URL : http://www.irena.org/-/media/Files/IRENA/Agency/Publication/2018

7. Renewables 2016 Global Status Report, http://www.ren21.net/statusofrenewables/global-status-report/ 